\title{
Progress on Autosomal Dominant Polycystic Kidney Disease
}

\author{
Elwaleed Elhassan, Amirali Masoumi and Robert W Schrier* \\ Division of Renal Diseases and Hypertension, School of Medicine, University of Colorado Denver, USA
}

\begin{abstract}
Introduction: Autosomal dominant polycystic kidney disease (ADPKD) is the most common life threatening hereditary disease of the kidney. It is a systemic disease characterized by multiple, bilateral renal cysts that result in massive renal enlargement and progressive functional impairment. This review discusses the current understanding of the epidemiology, genetics, clinical manifestations, natural history of the disease, the accuracy and reliability of diagnostic approaches, renal replacement therapy and emerging therapeutic strategies that are being evaluated in ADPKD.
\end{abstract}

Review: ADPKD is a genetically heterogeneous disease with significant inter-familial and intra-familial variability. The responsible genes were localized to separate loci on chromosome 16 (PKD1 gene) accounting for the majority of ADPKD cases, and chromosome 4 (PKD2 gene) accounting for the remainder. Each child of an affected parent has a $50 \%$ chance of inheriting the mutated gene, which is completely penetrant. Clinical manifestations include renal and cyst enlargement, impaired urine concentration capacity, hematuria, nephrolithiasis, proteinuria, hypertension, polycystic liver disease, abdominal wall hernia and intracranial aneurysms. The diagnosis of ADPKD usually relies on renal imaging. Ongoing research has engendered crucial insight into the disease's underlying genetic, cellular and pathogenetic mechanisms and made possible the design and implementation of clinical trials testing promising treatments. Renin Angiotensin Aldosterone System (RAAS) blockade, vasopressin antagonists, somatostatin, rapamycin, sirolimus and everolimus are currently being evaluated for a potential therapeutic role in the management of ADPKD.

Conclusion: Current clinical trials investigating multiple therapeutic targets bring hope for treatments that may impede the progression of ADPKD.

\footnotetext{
* Corresponding author; Division of Renal Diseases and Hypertension, University of Colorado Denver, 12700 East 19th Avenue, C281, Aurora, Colorado 80045, USA; E mail: Robert.schrier@ucdenver.edu
}

keywords: ADPKD, autosomal dominant polycystic kidney disease, kidney failure

\section{Introduction}

Autosomal dominant polycystic kidney disease (ADPKD) is the most common inheritable disorder of the kidney. It affects all racial groups worldwide, with a frequency of 1:400 to 1:1000 live births [1]. ADPKD is the fourth most common cause for end-stage renal disease (ESRD) worldwide and accounts for $5-10 \%$ of renal transplant recipients, making it a major global health care burden $[1,2]$. It is a systemic disease characterized by multiple, bilateral renal cysts that arise typically from nephron segments, resulting in massive renal enlargement and progressive functional impairment. The onset of the disease is bimodal, with most patients presenting in the third to fifth decades of life and a clinically significant subset of patients presenting in infancy and childhood. Typically, only a few renal cysts are detected in most affected individuals before 30 years of age. However, by the fifth decade of life, numerous renal cysts will be found in the majority of patients. Patients with established disease can have their enlarged kidneys each measure up to $40 \mathrm{~cm}$ in length (compared with 10 to $12 \mathrm{~cm}$ in normal kidneys) and weigh up to $8 \mathrm{~kg}$ (compared with 400 to $500 \mathrm{~g}$ in normal kidneys) [3]. The degree of kidney enlargement, in turn, correlates with complications such as pain, hematuria, hypertension, and renal insufficiency. Numerous renal and extrarenal manifestations have been described for ADPKD. The typical adult presentation includes decreased renal concentrating ability, hematuria, and flank pain resulting from cyst expansion. Hypertension, left ventricular hypertrophy (LVH), cardiac valvular defects, back and abdominal pain, cerebral aneurysms, and liver cysts are the most important clinical findings.

\section{Genetics}

ADPKD is genetically heterogeneous with separate loci on chromosome 16 (PKD1), accounting for approximately $85 \%$ of ADPKD cases, and on chromosome 4 (PKD2), 
Figure 1: Structure of polycystin-1 and polycytin-2*

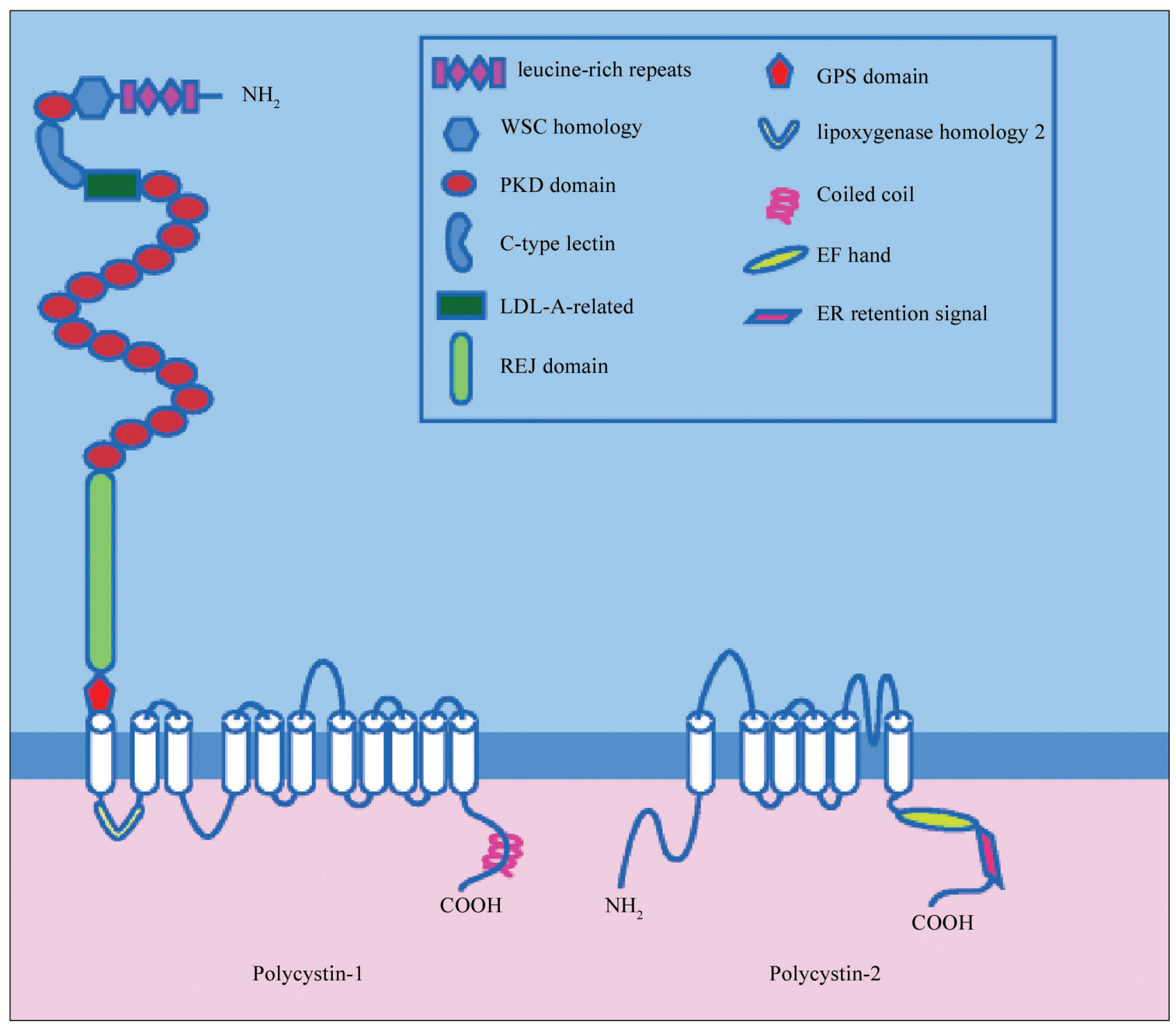

* Reproduced with permission [9]

accounting for approximately $15 \%$ of patients [4]. PKD1 and PKD2 genes encode plasma membrane-spanning proteins polycystin-1 and polycystin-2 respectively (Figure 1). The polycystins regulate tubular and vascular development in the kidneys and other organs (liver, brain, heart, and pancreas) and interact to increase the flow of calcium through a cation channel formed in plasma membranes by polycystin-2 [5].

A mutation of either polycystin can disrupt the function of the other, resulting in similar clinical presentations. Recently a third gene, PKD3, has been suspected in few families but has not yet been identified. Each child of an affected parent has a $50 \%$ chance of inheriting the mutated gene, which is completely penetrant. ADPKD arises as a spontaneous mutation in approximately $5 \%$ of cases. However, in about one fourth of newly diagnosed cases, patients report no family history of the disease, indicating that many familial cases go undetected. The disease has large interfamilial and intrafamilial variability in the severity of renal and extrarenal manifestations pointing to genetic and environmental modifying factors [6]. Mutations on PKD1 gene are likely to be associated with more renal cysts, and to lead to renal insufficiency on average 20 years earlier (median ages at the time of death or end stage renal failure with PKD1 and PKD2 mutations are 53 and 69 years, respectively) [7,8]. With both PKD1 and PKD2, older patients generally have more cysts, indicating that the cystogenesis continues throughout the life of patients. 
Table 1: Summary of the Consortium of Renal Imaging Studies in Polycystic Kidney Disease (CRISP) Studies Observations

- Liver cyst Disease: $94 \%$ prevalence of liver cystic disease by age 35, women affected more often than men [11].

- Genotype: PKD1 individuals demonstrate larger kidneys with more cysts than age-matched PKD2 individuals. Rates of change in cyst growth are similar between PKD1 and PKD2 individuals [7].

- Hypertension: hypertensive ADPKD individuals as compared to age matched normotensive ADPKD individuals demonstrate larger kidney volumes that grow at a faster rate [10].

- Kidney volume: increases over time with growth due to cyst expansion, associated with proteinuria and reduction in GFR [7].

- Renal blood flow: is reduced early in ADPKD, prior to loss of renal function and is associated with increased renal size [12, 13].

- Imaging: ultrasound versus MRI imaging demonstrates reduced reliability and reproducibility and decreasing correlations with MR-based estimates of renal volume as kidney size increases [14, 15].

\section{Clinical manifestations}

\section{Renal manifestations}

\section{Renal and cyst volume enlargement}

Kidney enlargement as a result of cyst expansion is the hallmark of ADPKD and this directly translates into the renal manifestations of the disease. Continued enlargement of the cysts often leads to progressive renal failure. Other renal manifestations include urinary tract infection, urinary concentrating defect, hematuria, nephrolithiasis and acute or chronic flank and abdominal pain. In comparison with glomerular filtration rate (GFR), which deteriorates very slowly in early stages of ADPKD and therefore is not a robust marker of disease progression, magnetic resonance imaging (MRI) assessment of renal volume seems to provide a promising tool for monitoring early disease progression and assessing the efficacy of therapeutic interventions. A study of 241 early ADPKD patients followed up prospectively with yearly MRI examinations by the Consortium of Radiologic Imaging Studies to assess the Progression of Polycystic kidney Disease (CRISP) has provided invaluable insight to understand how the cysts develop and grow (Table 1). In the CRISP study, Grantham et al demonstrated that renal enlargement occurs in a quantifiable, exponential manner and can be correlated directly with the decline in renal function $[7,10]$. Baseline total kidney volume predicted the subsequent rate of increase in renal volume and was associated with declining GFR in patients with baseline total kidney volume above $1500 \mathrm{ml}$. Kidney and cyst volumes consistently increased in both the PKD1 and PKD2 populations but the absolute rate of change was greater in PKD1 (74.9 ml/year) than PKD2 (32.2 ml/ year). However, this was due to the larger baseline sizes of the kidneys; the rates of growth for kidney and cyst volume were not significantly different $(5.68 \%$ per year for PKD1 vs. $4.82 \%$ per year for PKD2). This indicates that gene type does not strongly influence the size of ADPKD kidneys by modulating the relative rate of cyst growth but rather by cyst initiation. Gender, however, affected both the absolute and relative rates of kidney and cystic expansion in the ADPKD population, with male patients showing more rapid expansion.

\section{Concentration impairment}

Impaired urinary concentrating capacity is common even at early stages [16]. Plasma vasopressin concentrations are increased; therefore a central cause has been excluded [17]. The underlying mechanism is not known, but disruption of tubular architecture, defects in principal cell function, or early tubulointerstitial disease are postulated factors. Recent studies suggest that the urinary concentrating defect and raised vasopressin concentrations could contribute to cystogenesis [18]. Defective medullary trapping of ammonia and transfer to the urine caused by the concentrating defect could contribute to the low urine $\mathrm{pH}$ values, hypocitric aciduria, and predisposition to stone formation [19].

\section{Hematuria}

Rupture of a cyst into the collecting system is thought to be responsible for the development of hematuria. Although hemorrhage into a cyst is also common, the typical presentation is pain rather than hematuria since many cysts do not communicate with the collecting system [20]. Hematuria occurs at some time in the course of the disease in $42-50 \%$ of ADPKD patients and may be the initial diagnostic clue [21]. Both kidney size and hypertension have direct correlation with the incidence of gross hematuria. Nephrolithiasis is another cause of hematuria. Hematuria usually resolves within two to 
seven days with conservative therapy consisting of bed rest and hydration.

\section{Nephrolithiasis}

Kidney stones occur in approximately $20 \%$ of patients with ADPKD [22]. The composition of the stones is most frequently uric acid and/or calcium oxalate. Metabolic factors are important in their pathogenesis as well as mechanical distortions induced by large cysts. As discussed above, aciduria and hypocitruria due to abnormal ammonium transportation are the most common abnormalities while distal acidification defects may be important in a few patients. Unlike other cases of nephrolithiasis, it is more difficult to establish the diagnosis by ultrasonography in ADPKD patients, because of the large cysts and calcifications which may be present in the cyst walls. Most stones can be detected by intravenous pyelography, but CT scanning is more sensitive for the detection of small or radiolucent stones [22]. A patient with nephrolithiasis is given the same treatment whether or not they have a concurrent diagnosis of ADPKD. Extracorporeal shock wave lithotripsy (ESWL) and percutaneous nephrolithotomy in patients with early disease and normal renal function are not contraindicated.

\section{Proteinuria}

Proteinuria is not considered a major feature of ADPKD. However, the presence of proteinuria may be an indicator of sub-clinical other end-organ damage, including left ventricular hypertrophy (LVH) and systemic atherosclerosis. Recent studies have shown significant association between left ventricular mass index (LVMI) and proteinuria $[23,24]$. In ADPKD patients, proteinuria is considered an important predictor of renal disease progression. In a study of 270 ADPKD patients, only 48 (18\%) of subjects had overt proteinuria ( $>300 \mathrm{mg}$ per day) [25]. Interestingly, all these patients had hypertension and large renal volumes. The same group of patients had greater renal functional impairment, faster disease progression and an increased incidence of hematuria [24]. A 5-year prospective, randomized study of 24 ADPKD patients examined the anti-albuminuric effect of amlodipine, a calcium channel blocker, versus enalapril, an angiotensin converting enzyme (ACE) inhibitor. Albumin to creatinine ratio increased significantly in the amlodipine-treated, but was stable in the enalapril-treated group at comparable levels of blood pressure (BP) control [26]. We can therefore propose that the sustained antialbuminuric effect of ACE inhibitors may improve the long-term renal and cardiovascular prognosis in ADPKD patients.

\section{Hypertension}

Hypertension is the most common complication of ADPKD, occurring in approximately $60 \%$ of patients before any significant reduction in glomerular filtration rate $[27,28]$. Hypertension is diagnosed at a much earlier age in ADPKD patients, with a median of 32 years in males and 34 years in females [29]. Prevalence of hypertension in children with ADPKD is between 5\% and 44\%, but is difficult to ascertain accurately because of selection biases and the different definitions of hypertension used in different studies [30]. Several studies have shown that hypertension in ADPKD is associated with increased renal volume and LVMI, in both adults and children. Hypertension and LVMI are important risk factors for cardiovascular disease, which is the most common cause of death in patients with ADPKD [31-33].

There is evidence that early activation of the reninangiotensin system is important in the pathogenesis of hypertension in ADPKD. Angiographic studies have demonstrated that cyst enlargement in ADPKD is associated with compression of the adjacent parenchyma and vasculature [34, 35]. Several studies have indicated increased concentrations of renin in both tissue and cyst fluid from ADPKD patients [36]. Moreover, further studies have shown an intrarenal role of renin angiotensin aldosterone system (RAAS) in the pathogenesis of ADPKD. This is indicated by detecting the angiotensinogen, angiotensin-converting enzyme (ACE), angiotensin II type-1 (AT1) receptor, and angiotensin II within cysts and tubules of ADPKD kidneys [37]. These results suggest activation of the RAAS secondary to renal ischemia.

Other factors proposed to contribute to hypertension in ADPKD include increased sympathetic nerve activity and increased plasma endothelin-1 concentrations [38, 39]. AT1 is known to stimulate the pro-fibrogenic cytokine, transforming growth factor beta. This is an important finding as renal interstitial fibrosis is a hallmark of ADPKD. Angiotensin II may also have proliferative effects on tubular epithelial cells via epidermal growth factor (figure 2) [40, 41].

In ADPKD, hypertension often remains undiagnosed until late in disease progression. Twenty four hour ambulatory BP monitoring of children or young adults without hypertension can reveal raised BP, attenuated nocturnal blood-pressure dipping and exaggerated blood-pressure response during exercise, which can be accompanied by LVH and diastolic dysfunction [43]. Hypertension and subsequent $\mathrm{LVH}$ are important risk factors for cardiovascular disease, which is the most common cause of death in patients with ADPKD. Uncontrolled BP also increases the risk for proteinuria, hematuria, decline of 
Figure 2: Multifactorial pathogenic role of angiotensin II in hypertension and renal disease association with autosomal dominant polycystic kidney disease

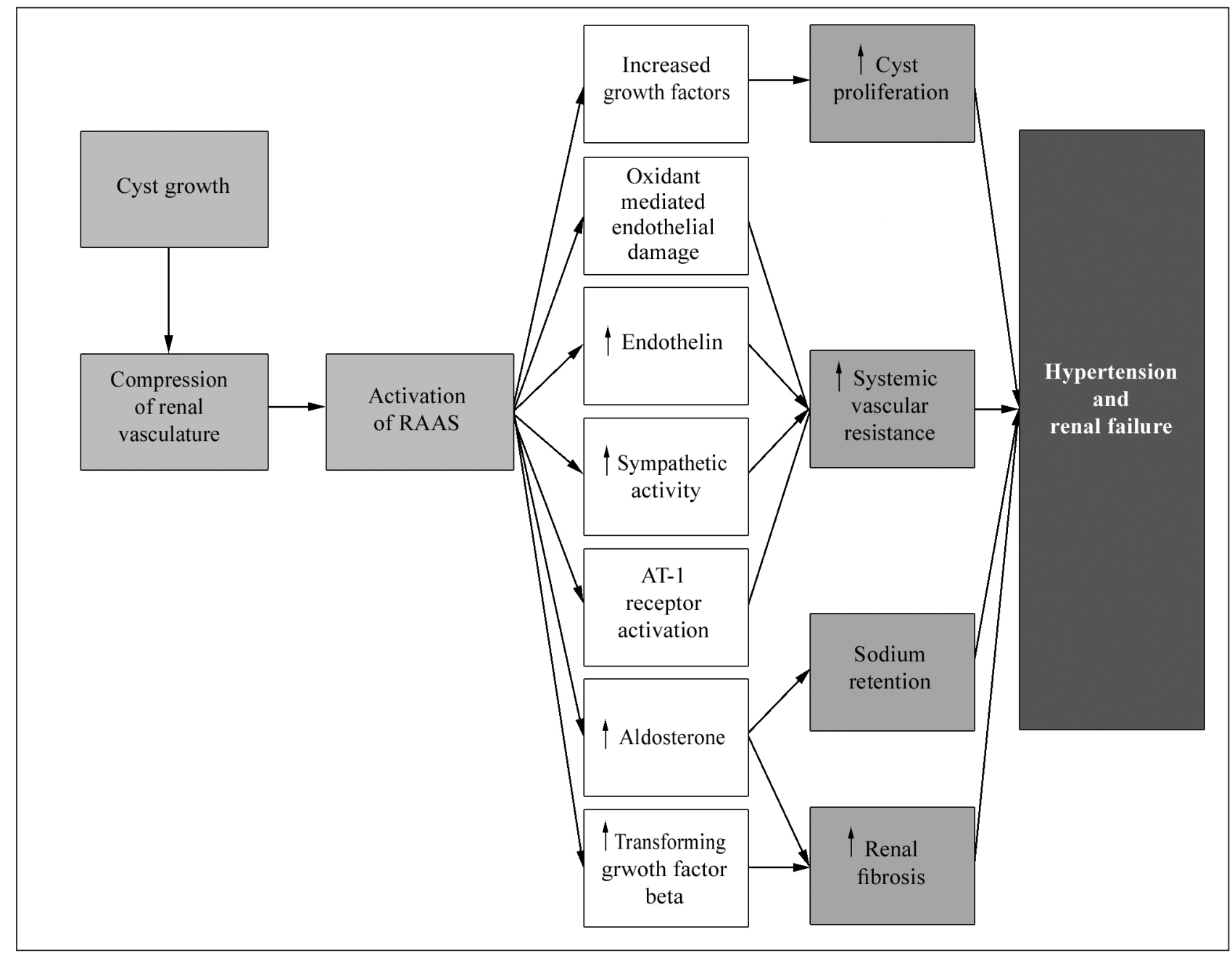

* Reproduced with permission [42]

renal function, and morbidity and mortality from valvular heart disease and aneurysms. Thus, early detection and treatment of hypertension is important [26, 33, 44]. Moreover, the presence of hypertension increases the risk of pre-eclampsia and fetal loss, while normotensive ADPKD women usually have uncomplicated pregnancies [45].

\section{Extra-renal manifestations}

\section{Polycystic liver disease}

Polycystic liver disease is the most common extrarenal manifestation of ADPKD. It is associated with both PKD1 and PKD2 genotypes and may also occur as a distinct disease in the absence of renal cysts [46, 47]. The frequency of hepatic cysts increases with age and may have been underestimated by ultrasound and CT studies. The prevalence of hepatic cysts detected by MRI in the
CRISP study was $58 \%$ in $15-24$ year olds, $85 \%$ in $25-34$ year olds, and $94 \%$ in 35-46 year old participants [11]. Hepatic cysts are more common and larger in volume in female than male patients. Women with multiple pregnancies or history of oral contraceptives may present with more severe disease, suggesting an effect of estrogen on hepatic-cyst growth without a significant effect on renal volume [48].

Liver cysts arise by excessive proliferation and dilatation of biliary ductules and peri-biliary glands. Growth of liver cysts is promoted by estrogen receptors which are expressed in the epithelial lining of the cysts as well as by growth factors and cytokines secreted into the cyst fluid $[49,50]$.

Hepatic cysts are typically asymptomatic but symptoms might increase as the life spans of polycystic disease 
patients are prolonged by dialysis and transplantation. Liver function tests are usually normal in ADPKD patients with liver involvement. Despite the progressive nature of the cystic disease, the hepatic parenchyma remains normal, both histologically and physiologically [51]. Symptoms may arise from mass effects or from complications related to the cysts. Mass effects from enlarging cysts and hepatomegaly include dyspnea, early satiety, gastro-esophageal reflux, mechanical low back pain and abdominal hernias. Pain is the most disabling complication of polycystic liver disease. Other complications are hepatic venous outflow obstruction, compression of the inferior vena cava, portal-vein compression, or bile-duct compression presenting as obstructive jaundice [52].

In asymptomatic patients, no treatment is indicated for polycystic liver disease. In the symptomatic patient, surgery is the mainstay of treatment tailored to the extent of the disease for each patient. Management options include cyst aspiration and alcohol sclerosis, open or laparoscopic fenestration, liver resection with fenestration, and liver transplantation [53]. Acute hepatic cyst complications are cyst hemorrhage and infection. Right abdominal pain accompanied with fever and leukocytosis in ADPKD patients could result either from right kidney or liver cyst infection [54]. The incidence of bacteremia is high with infected liver cysts and is detected in about $63 \%$ of cases with positive blood cultures. Common organisms are gram-negative bacteria such as E.coli [55]. Infected liver cysts should be diagnosed and treated aggressively. Blood and/or cyst fluid cultures are necessary. In contrast to renal cyst infections, both antibiotic therapy and percutaneous cyst drainage under ultrasound or CT guidance should be employed in infected liver cysts. The antibiotics administered should be capable of penetration into liver cysts, such as ciprofloxacin or amikacin. Cyst hemorrhage may present with similar findings to an infected liver. This is a rare complication, which is best diagnosed by MRI.

\section{Cysts in other organs}

Cysts of the seminal vesicles, pancreas, and arachnoid membrane are present in $40 \%$ (of men), $5 \%$, and $8 \%$ of patients respectively $[56,57]$. Seminal vesicle cysts rarely result in infertility. Pancreatic cysts are almost always asymptomatic, with very rare instances of recurrent pancreatitis [58]. Arachnoid membrane cysts are often asymptomatic, but can increase the risk of subdural hematomas [59]. Spinal meningeal diverticula can occur with increased frequency and rarely present with intracranial hypotension due to cerebrospinal fluid leak [60].

\section{Abdominal wall hernia}

Compared to patients with renal failure due to other causes, ADPKD patients have a significantly higher incidence of abdominal wall hernia that appears to be due to the underlying defect in extracellular matrix production. A retrospective review compared ADPKD patients on dialysis with age- and sex-matched renal failure patients without ADPKD and with general surgical patients. In this study, a hernia was present in 38 of 85 (45\%) ADPKD patients compared to seven of $85(8 \%)$ patients with other forms of renal failure and three of 85 (4\%) general surgical controls $(\mathrm{P}<0.001)$. There were significantly greater numbers of inguinal, incisional and para-umbilical hernias in patients with ADPKD compared with the other two groups [61].

\section{Intracranial aneurysms}

Serious extra-renal manifestations of ADPKD include intracranial aneurysms (ICAs) and rupture of intracranial aneurysms (RICAs). ICAs are seen in approximately $4-11.7 \%$ of ADPKD patients compared to $1-5 \%$ of the general population. ICAs are more common in those with a family history of this condition [62-64]. The risk of subarachnoid hemorrhage (SAH) is approximately five-fold higher in ADPKD patients compared to the general population [65]. ICAs are usually asymptomatic. Aneurysmal rupture carries a $35-55 \%$ risk of combined severe morbidity and mortality [66]. RICAs are responsible for $4-7 \%$ of deaths in patients with ADPKD and hemorrhage tends to occur at a younger age (mean age of 35-45 years) than in the general population [36, 39]. Most patients have normal renal function and up to $29 \%$ have normal $\mathrm{BP}$ at the time of rupture. Because of family clustering, a family history of a ruptured ICA is an indication for screening imaging $[67,68]$. Other indications for screening include previous aneurysm rupture, preparation for major elective surgery that is likely to be associated with hemodynamic instability and hypertension, high-risk occupations (e.g. airline pilots), and patient anxiety despite adequate information [69]. Magnetic resonance angiography (MRA) is currently the preferred screening procedure for ICA in ADPKD [70]. However, it is recommended that gadoliniumbased imaging be avoided, if possible, in patients with an estimated GFR less than $30 \mathrm{ml} / \mathrm{min}$ because of the newly recognized severe nephrogenic systemic fibrosis syndrome, which has been linked to gadolinium. Whether to expose patients with an estimated GFR of $30-60 \mathrm{ml} / \mathrm{min}$ to gadolinium or not is controversial. When an asymptomatic ICA is found, the advisability of intervention depends on cyst size, site, and morphology as well as history of SAH from another aneurysm, patient's age and general health, and whether the 
aneurysm is suitable for coiling or clipping [71]. The risk of new aneurysms development or existing aneurysm enlargement is very low in ADPKD patients with small $(<7 \mathrm{~mm})$ asymptomatic aneurysms and moderate in those with history of rupture in a different site [72]. Therefore, conservative management is usually recommended for patients with small $(<7 \mathrm{~mm})$ aneurysms, particularly in the anterior circulation. Semiannual or annual repeat imaging studies are appropriate initially, but reassessment at less frequent intervals might be sufficient once the stability of the aneurysm has been documented. Symptomatic aneurysms of any size and those 7-10 $\mathrm{mm}$ in diameter should be corrected surgically or by endovascular repair, since these lesions have a high risk of rupture (up to $2 \%$ per year for larger aneurysms) [73]. Patients with aneurysms who are managed conservatively should be instructed to avoid uncontrolled hypertension, smoking, heavy alcohol consumption, stimulant medications, illicit drugs, and excessive straining.

\section{Cardiac manifestations}

A significant correlation between LVMI and mean arterial pressure in adults with ADPKD has been observed. ADPKD children with hypertension also have an increased LVMI compared to normotensive ADPKD children [74]. An increase in LVMI may be detected earlier than an increase in renal volume in children with ADPKD and borderline hypertension, suggesting that close monitoring of cardiac status is indicated in these children [75]. Hypertension, particularly when associated with LVH, has emerged as the most frequent and treatable complication in ADPKD patients [76]. This is of particular relevance, since in the present era of renal replacement therapy cardiovascular complications are the most frequent cause of death in ADPKD [33].

Valvular abnormalities detected by echocardiography are more frequent in ADPKD patients compared to the general population. Mitral valve prolapse (MVP) is the most common disorder (26-31\% vs. 2\%) followed by aortic regurgitation (8\%) $[77,78]$. Although most patients are asymptomatic, the lesions may progress over time and become severe enough to require valve replacement [79].

\section{Pain}

Acute or chronic pain is known as the most common complaint among ADPKD patients; approximately $60 \%$ of ADPKD patients experience abdominal and flank pain $[20,80,81]$. The most common etiologies of acute pain are cyst rupture, hemorrhagic or infected cysts, urinary tract infection and nephrolithiasis. While cyst infection clinically mimics pyelonephritis, the former presents with low-grade fever and more localized, non-positional flank pain [82]. Blood cultures are the most reliable diagnostic tests in identifying cyst infection [83]. The best imaging diagnostic method for infected cysts are contrast enhanced CT or MRI and scintigraphy with indium-111 labeling of leukocytes $[84,85]$. Infected cysts should be treated with lipophilic agents such as clindamycin, ciprofloxacin, norfloxacin, and trimethoprim-sulfamethoxazole, for a course of six weeks. In ADPKD patients who have undergone treatment for urinary tract infection (UTI), the persistence of severe pain and more serious complications indicates perinephric abscess and may require surgical intervention [86].

Basic analgesic therapy with non-steroidal antiinflammatory drugs (NSAIDs) for 2-3 days might be helpful in ADPKD patients with renal colic [87-89]. Multiple studies have indicated no difference between the usage of NSAIDs and opioids in the treatment of colic due to renal stones. It has been shown that ESWL and nephrolithotomy may provide favorable results in symptomatic ADPKD patients with renal calculi [90, 91].

Due to continuous cytogenesis and progressive kidney enlargement, mostADPKD patients will experience a dull, chronic flank discomfort. This pain might be due to renal capsule traction or related to asymmetric lumbosacral muscle hypertrophy [82]. Optional treatments consist of physical therapy measures (e.g. heating pads, ice massage), psychobehavioral modification techniques, and systemic analgesics. Physical interventions might also be beneficial such as transcutaneous electrical nerve stimulation (TENS), autonomic plexus blockade, neuromodulation by spinal cord stimulation, neuraxial opioids and local anesthetics, surgical decompression of kidney and liver cysts, partial hepatectomy and/ or nephrectomy $[82,92]$. In one study of 15 ADPKD patients with uncontrolled abdominal pain and large cysts, cyst decompression using 99\% ethanol resulted in remarkable pain relief. Considering the small size of this study population, more evaluation for this safe, cost effective therapy is needed [93]. On the other hand, a recent follow-up study of 12 pediatric patients showed promising results for laparoscopic renal denervation and nephropexy as a therapeutic option in severe chronic ADPKD-related pain [94].

\section{ADPKD in children}

Although ADPKD is often considered an adult disease, early studies have described the presence of the disease in childhood and even in utero $[95,96]$. Clinical findings in ADPKD children vary. However, hypertension and flank and/or low back pain are very common. These findings are significantly associated with larger kidneys and 
increased cyst numbers $[43,86]$. Polyuria and impaired urinary concentration are also correlated with larger renal volumes [97]. Similar to adults, liver cysts may be the most common extra-renal manifestation in ADPKD children [41]. A recent study of 85 ADPKD children and adolescents conducted at the University of Colorado Health Sciences Center showed a significant correlation between both systolic and diastolic BP and LVMI. The study population was categorized into three levels of BP; hypertensive (BP greater than the 95th percentile for gender, age, and height), borderline hypertensive (BP within 75-95th percentile), and normotensive (BP less than 75 th percentile). Surprisingly, when compared to the normotensive group, children with borderline hypertension had significantly elevated LVMI [75]. Due to the significant association between larger kidneys and early progression to ESRD, it is imperative to explore the beneficial effects of reducing renal growth and LVMI through early intervention with RAAS blockers.

\section{Diagnosis}

The diagnosis of ADPKD usually relies on renal imaging. Characteristic findings include large kidneys and numerous cysts scattered throughout both kidneys. Ultrasonography (US) is the most commonly used imaging modality though in certain settings genetic counseling and mapping is required for a definitive diagnosis.

Counseling should be offered to patients prior to testing [98]. Despite the absence of curative therapy, earlier confirmation of the diagnosis could have several beneficial effects. These include allowing appropriate family planning, instituting early treatment for hypertension to prevent LVH and cardiovascular complications and slow renal disease progression and selecting genetically unaffected family members for living related donor transplantation. On the other hand, early diagnosis in young individuals could be perceived to result in emotional and career consequences as well as removal of the choice to know. Until effective therapies are available, the decision of testing should be made in collaboration with well informed subjects and their families. Nevertheless, children at risk for ADPKD should be monitored as hypertension is frequently underdiagnosed and inadequately treated.

Renal US is widely used for pre-symptomatic screening of at risk individuals and for evaluation of potential living-related kidney donors from families with ADPKD. Pei et al have recently revised the US diagnostic criteria for ADPDK, as previously used criteria tended to under-diagnose the disease in PKD2 gene carriers [99]. They screened 577 and 371 at-risk individuals from 58
PKD1 and 39 PKD2 families respectively with renal US, using molecular genotyping as the gold standard for disease assignment. The presence of three or more (unilateral or bilateral) renal cysts was found sufficient for establishing the diagnosis in individuals aged 15-39 years. By contrast, more stringent criteria are required for the older age groups because of increasing prevalence of simple renal cysts. The presence of two or more cysts in each kidney was found sufficient for individuals aged 40-59 years, and four or more cysts in each kidney is required for individuals $\geq 60$ years. Conversely, fewer than two renal cysts in at-risk individuals aged $\geq 40$ years is sufficient to exclude the disease. The utility of US for disease exclusion may be limited in at-risk individuals who are younger than 30 years and have a negative or indeterminate scan. In these individuals, repeat ultrasound scanning every 6 to 12 months may be helpful to detect new cysts. However, if these individuals are being evaluated as potential living-related kidney donors, then molecular genetic testing is justified [99]. Because CT and MRI are more sensitive than US, the aforementioned sonographic criteria are not applicable to these modalities.

In up to $25 \%$ of ADPKD cases there may be no family history of the disease. Such instances may occur when an affected parent has not been diagnosed or is suffering from a mild form of the disease. In up to $5 \%$ of cases, the disease may be due to a new mutation. In such cases, bilateral renal enlargement and cysts or the presence of multiple bilateral cysts with hepatic cysts together with the absence of other manifestations suggesting a different renal cystic disease provide presumptive evidence for the diagnosis. See Table 2 for the differential diagnosis of ADPKD.

In acquired renal cystic disease associated with longstanding renal insufficiency, the kidneys are initially small. With time they can enlarge and resemble those of ADPKD. Localized renal cystic disease, characterized by non-progressive cystic transformation of a portion of a kidney, should be differentiated from asymmetric presentations ofADPKD, segmental multicystic dysplasia, and cystic neoplasms. In rare cases, medullary sponge kidney, a disorder characterized by tubular dilatation of the collecting ducts confined to the medullary pyramids, can mimic the urographic appearance of ADPKD. The absence of family history of the disease and sparing the renal cortex on $\mathrm{CT}$ or MRI point to the right diagnosis. Genetic testing can be used when the imaging results are equivocal or when a definite diagnosis is required in a younger individual, such as a potential living related kidney donors. Genetic testing can be done by linkage or direct DNA sequence analysis. The choice of performing either linkage or sequence analysis largely depends upon 
Table 2: Differential diagnosis of autosomal dominant polycystic kidney disease

\begin{tabular}{|c|c|c|}
\hline Renal cystic disorder & $\begin{array}{l}\text { Prevalence } \\
\text { and inheritance }\end{array}$ & Distinguishing clinical findings \\
\hline $\begin{array}{l}\text { Tuberous sclerosis } \\
\text { complex (TSC) }\end{array}$ & $\begin{array}{l}1 \text { in } 10000 \text {, } \\
\text { autosomal dominant }\end{array}$ & $\begin{array}{l}\text { Skin lesions (facial angiofibromas, periungual fibroma, hypomelanotic } \\
\text { macules, Shagreen patch), retinal hamartomas, seizures, mental retardation, } \\
\text { cortical tuber, subependymal giant cell astrocytoma, cardiac rhabdomyoma, } \\
\text { lymphangioleiomyomatosis, renal angiomyolipoma. Contiguous deletion of } \\
\text { PKD1 and TSC2 results in severe polycystic kidney disease in infancy or early } \\
\text { childhood with ESRD typically occurring in the first two decades of life. }\end{array}$ \\
\hline $\begin{array}{l}\text { Autosomal recessive } \\
\text { polycystic kidney disease } \\
\text { (ARPKD) }\end{array}$ & $\begin{array}{l}1 \text { in } 20000 \text {, } \\
\text { autosomal recessive }\end{array}$ & $\begin{array}{l}\text { Collecting duct ectasia and/or macrocystic changes, nephrolithiasis, hyperten- } \\
\text { sion, impairment of renal function, hepatic fibrosis and portal hypertension or } \\
\text { ascending cholangitis. }\end{array}$ \\
\hline $\begin{array}{l}\text { Von Hippel-Lindau } \\
\text { syndrome }\end{array}$ & $\begin{array}{l}1 \text { in } 50000 \text {, } \\
\text { autosomal dominant }\end{array}$ & $\begin{array}{l}\text { Retinal hemangiomas, clear cell carcinomas of the kidney, cerebellar and } \\
\text { spinal hemangioblastomas, pheochromocytoma, endocrine pancreatic tumors, } \\
\text { and/or epididymal cystadenoma }\end{array}$ \\
\hline Medullary sponge kidney & $\begin{array}{l}1 \text { in } 5000 \text {, } \\
\text { autosomal dominant }\end{array}$ & $\begin{array}{l}\text { Tubular dilatation of the collecting ducts confined to the medullary pyramids, } \\
\text { medullary nephrocalcinosis, "paint brush" appearance of renal papillae on } \\
\text { intravenous pyelogram }\end{array}$ \\
\hline Orofaciodigital syndrome & $\begin{array}{l}\text { very rare, } \\
\text { X-linked dominant }\end{array}$ & $\begin{array}{l}\text { Lethal in affected male individuals, oral anomalies (hyperplastic frenula, cleft } \\
\text { tongue, cleft palate or lip, and malposed teeth), facial anomalies (broad nasal } \\
\text { root with hypoplasia of nasal alae and malar bones), and digital anomalies }\end{array}$ \\
\hline $\begin{array}{l}\text { Acquired } \\
\text { renal cystic disease }\end{array}$ & Common & $\begin{array}{l}\text { Chronic renal failure or ESRD particularly on renal replacement therapy with } \\
\text { multiple renal cysts associated with normal-sized or small kidneys and absent } \\
\text { extra-renal manifestations of ADPKD. }\end{array}$ \\
\hline $\begin{array}{l}\text { Localized } \\
\text { renal cystic disease }\end{array}$ & Uncommon & $\begin{array}{l}\text { Multiple cysts of various sizes separated by normal or atrophic parenchyma } \\
\text { involving one kidney. Rare under } 30 \text { years but incidence increases with age }\end{array}$ \\
\hline
\end{tabular}

which technique is feasible and available. A combined approach using both modalities may be most effective. This was shown in a study in which genetic linkage and direct DNA analysis was performed in patients from families with and without history of disease. Among two prospective kidney donors with positive family history, the use of both linkage and DNA sequencing was required to definitively exclude the presence of ADPKD [100].

\section{Therapy}

\section{Renin Angiotensin Aldosterone System (RAAS) blockade}

RAAS activation has been demonstrated in ADPKD patients and therapy directed towards its inhibition has been shown to effectively reduce $\mathrm{LVH}$ and proteinuria [101]. These findings are very important because LVH is a major risk factor for systolic and diastolic dysfunction, cardiac arrhythmias, sudden death and ischemic heart disease. The degree of proteinuria has been also shown to be a predictor of renal disease progression in a variety of chronic renal diseases (e.g. diabetic nephropathy, glomerulonephritis) as well as in ADPKD [102-104].
In spite of that, studies have not demonstrated a renoprotective effect of ACE inhibitors or angiotensin receptor blockers (ARB) in ADPKD. In the Modification of Diet in Renal Disease (MDRD) study, which was designed to assess the role of dietary protein and phosphorous intake and level of BP control on renal disease progression, 200 of 840 subjects had ADPKD. Overall, there was no significant reduction in GFR decline in those treated with either the low-protein diet or low BP, and ACE inhibitors were used in approximately 40\% [105]. This study, however, was not designed to randomly assign patients with regard to angiotensin blocking agents. Maschio et al performed a prospective, randomized, double-blind placebo-controlled study to assess the benefits of ACE inhibition on renal progression in non-diabetic kidney disease (including patients with ADPKD). There was a lack of therapeutic efficacy in 64 ADPKD patients followed for about 3 years. Ramipril was the ACE inhibitor used and there was a doubling of serum creatinine with equal frequency when compared to a placebo-controlled group. One of the limitations of the study was a reduced GFR at the onset of intervention (a mean creatinine clearance of $42 \mathrm{ml} / \mathrm{min}$ ) in the study group [106]. Patients may 
have had advanced disease that was not amenable to any treatment. In a 7-year prospective trial assessing both the level of BP control and the class of antihypertensive agent used, no advantage of an ACE inhibitor (enalapril) versus a calcium channel blocker (amlodipine) was found in reducing the rate of decline in glomerular filtration rate in ADPKD patients as estimated by the MDRD equation. A significantly better reversal of LVH was however shown with ACE inhibitor versus the calcium channel blocker as well as a BP of less than 120/80 $\mathrm{mmHg}$ as compared to $135-140 / 85-90 \mathrm{mmHg}$ [107]. Importantly, all of these studies evaluated relatively small numbers of patients for short periods of time after kidney insufficiency was established [108].

Clinical data support the hypothesis that the RAAS is activated in individuals with ADPKD. Normalization of renal blood flow in hypertensive ADPKD individuals with $\mathrm{ACE}$ inhibitors or an $\mathrm{ARB}$ is not complete since these agents result in incomplete inhibition of the RAAS, as aldosterone and angiotensin II are generated via multiple pathways. There is information that over time aldosterone and angiotensin "breakthrough" occurs in a significant number of patients receiving ACE inhibitors. Moreover, patients who demonstrate this "breakthrough" appear to have a worse outcome [109]. It is for these reasons that the HALT PKD Study aims to determine the efficacy of aggressive RAAS blockade utilizing a combination of an ACE inhibitor plus an ARB or placebo in slowing renal function decline in ADPKD [110]. This prospective randomized double blind clinical trial is underway. It is being funded by the National Institute of Health and is conducted at seven centers throughout the United States to recruit over a thousand individual with ADPKD, both early (study A: estimated GFR $\geq 60 \mathrm{ml} / \mathrm{min}$ ) and late (study B: estimated GFR 26-59 $\mathrm{ml} / \mathrm{min}$ ). The hypothesis to be tested is that intensive blockade of the RAAS with combination ACE inhibitor and ARBs will delay the progression of renal disease independent of BP control in participants compared with ACE inhibitor monotherapy. Another hypothesis to be tested is that rigorous versus moderate BP control will be more effective in slowing progression of renal disease in early ADPKD. The ACE inhibitor lisinopril is prescribed for all patients in the study (both study A and B) along with either the ARB telmisartan or placebo in a randomized fashion. In study A, hypertensive ADPKD subjects with higher GFR are randomized to achieve standard (120-130/70-80 $\mathrm{mmHg}$ ) versus rigorous BP control $(95-110 / 60-75 \mathrm{mmHg})$. The primary end-point is the change in kidney volume measured by MRI whereas secondary outcomes include the rate of change in estimated GFR, change in renal blood flow and left ventricular mass using MRI, change in albuminuria, and PKD related symptoms. In study
$\mathrm{B}$, hypertensive ADPKD subjects with lower GFR are randomized to ACE inhibitor and placebo versus ACE inhibitor and ARB therapy with a standard BP goal (110$130 / \leq 80 \mathrm{mmHg}$ ). The primary outcome is the time to the composite endpoints of doubling of serum creatinine, ESRD, or death. The HALT PKD study will determine if the activation of the RAAS and hypertension play independent roles in structural progression of renal cysts in ADPKD. It will also test whether those interventions affect morbidity markers including left ventricular mass and proteinuria. This study will continue for 5 years, so the follow-up period can be adequate.

\section{Novel therapies}

Advances in the understanding of the genetics, molecular biology and pathophysiology of ADPKD have enabled new potential approaches that will hopefully have an effect on the disease. Recent studies indicated that cyclic adenosine monophosphate (cAMP) plays a central role in cystic fluid accumulation, cystogenesis and proliferation of cells derived from polycystic kidneys [111-113]. Vasopressin, via V2 receptor (VPV2R), activates adenylyl cyclase and cAMP production in cysts originated from principal cells of the collecting duct. Recent studies on murine cystic models, examining the effect of a non-peptide vasopressin antagonist (OPC-31260) have been conducted. The results indicated prevention of the renal cAMP accumulation, inhibition of renal cystogenesis, decreased kidney weights, and decreased blood urea nitrogen (BUN) [114, 115]. Additional studies were conducted to evaluate the effects of Tolvaptan (OPC-41061), a more potent vasopressin V2 antagonist. Currently two multicenter studies utilizing Tolvaptan (an open-label study and a phase 3, placebo-controlled, double-blind study) are in progress. Since hepatocytes lack VPV2Rs, these agents exerted no effect on polycystic liver disease. Increased water intake in rat PKD models for 10 weeks resulted in a protective effect on the development of the renal cystic disease, presumably due to vasopressin suppression [116]. Increased fluid intake, either by itself or together with the administration of V2 receptor antagonists, may therefore prove to slow the rate of growth of polycystic kidneys in humans [117].

Detection of the somatostatin receptor, subtype 2 (ss2), in kidney and hepatocytes and its inhibitory effect on cAMP, suggests a potential effect of somatostatin on cyst fluid secretion and enlargement in ADPKD patients [118]. Somatostatin has been tested in humans using a long-acting octreotide compound that is given intramuscularly every month for 6 months. Substantial retardation in kidney growth defined as change in kidney volume measured by CT imaging was found during the 
Table 3: Summary of existing drugs and potential experimental agents in the treatment of polycystic kidney disease ${ }^{*}$

\begin{tabular}{|c|c|c|c|c|}
\hline System & Drug & Mechanism & Pysiological effects & Trial results/status \\
\hline RAAS & Enalapril & ACE-inhibitor & $\begin{array}{l}\text { } \mathrm{RFP} \\
\uparrow \mathrm{GFR} \\
\downarrow \mathrm{F} . \mathrm{F} \\
\downarrow \mathrm{Alb} / \mathrm{Cr}(\mathrm{M}>\mathrm{F})\end{array}$ & $\begin{array}{l}\text { LVH reversal } \\
\downarrow \text { Albuminuria }\end{array}$ \\
\hline \multirow[t]{2}{*}{ Vasopressin } & $\begin{array}{l}\text { Mozavaptan (rat) } \\
\text { Tolvaptan (human) }\end{array}$ & V2-receptor antagonist & $\begin{array}{l}\downarrow \text { cAMP } \\
\downarrow \text { Ras } \\
\downarrow \text { ERK }\end{array}$ & $\begin{array}{l}\downarrow \text { Disease progression } \\
\text { Kidney weight } \\
\downarrow \text { BUN } \\
\text { NA in fibropolycystic liver disease }\end{array}$ \\
\hline & Water & AVP suppression & $\downarrow$ сAMP & $\begin{array}{l}\downarrow \text { Cyst growth } \\
\text { Kidney weight } \\
\uparrow \text { Renal function }\end{array}$ \\
\hline \multirow[t]{2}{*}{ Endothelin } & Bosentan & $\mathrm{ET}_{\mathrm{A} / \mathrm{B}}$ receptor antagonist & $\begin{array}{l}\uparrow_{\mathrm{MAP}} \\
\uparrow_{\mathrm{GFR}} \\
\uparrow_{\mathrm{RPF}}\end{array}$ & Acute treatment (rat) \\
\hline & $\begin{array}{l}\text { Darusentan } \\
\text { LU } 224332\end{array}$ & $\begin{array}{l}\mathrm{ET}_{\mathrm{A} / \mathrm{B}} \text { receptor antagonists } \\
\left(\text { especially } \mathrm{ET}_{\mathrm{A}}\right)\end{array}$ & $\begin{array}{l}\uparrow \text { Cyst volume } \\
\uparrow \text { Cell proliferation }\end{array}$ & $\begin{array}{l}\uparrow \text { Kidney weight } \\
\text { Not recommended }\end{array}$ \\
\hline Calcium channel & $\begin{array}{l}\text { Verapamil } \\
\text { BAPTA-AM }\end{array}$ & Calcium channel antagonist & $\uparrow \mathrm{cAMP}$ & \\
\hline mTOR & $\begin{array}{l}\text { Sirolimus } \\
\text { Temsirolimus } \\
\text { Everolimus }\end{array}$ & mTOR inhibitors & $\begin{array}{l}\downarrow \text { Cell proliferation } \\
\downarrow \text { Cyst volume } \\
\downarrow \text { Renal volume }\end{array}$ & Phase I and II clinical trials \\
\hline MEK & PD-098059 & MEK inhibitor & $\nabla$ Cell proliferation & \\
\hline Caspase & IDN-8050 & Pan-caspase inhibitor & $\begin{array}{l}\checkmark \text { Cyst volume } \\
\checkmark \text { Kidney size }\end{array}$ & Reduction in BUN (rat) \\
\hline Somatostatin & Octreotide & $\begin{array}{l}\text { Somatostatin receptor } \\
\text { type } 2 \text { agonist }\end{array}$ & $\begin{array}{l}\uparrow \text { cAMP } \\
\uparrow \text { PLC } \\
\uparrow \text { Phospholipase } \\
\downarrow \text { Cyst grwoth }\end{array}$ & 6 month clinical trial \\
\hline
\end{tabular}

AVP = arginine vasopressin; BUN = blood urea nitrogen; cAMP = cyclic adenosine monophosphate; ERK = extracellular signalregulated kinase; $\mathrm{ET}=$ endothelin; F.F = filtration fraction; GFR = glomerular filtration rate; $\mathrm{LVH}=$ left ventricular hypertrophy; $\mathrm{MAP}=$ mean arterial pressure; $\mathrm{MEK}=$ mitogen extracellular kinase; $\mathrm{mTOR}=$ mammalian target of rapamycin; $\mathrm{NA}=\mathrm{data}$ not available; PLC $=$ phospholipase C; RAAS = renin-angiotensin-aldosterone system; RPF = renal plasma flow; V2= vasopressin 2; $\uparrow$ indicates increase; $\downarrow$ indicate decrease

* Reproduced with permission [42]

period of octreotide therapy as compared with placebo ( $2.2 \pm 3.7$ versus $5.9 \pm 5.4 \%$ /year; $\mathrm{P}<0.01)$.

Recent studies indicate that ADPKD patients have increased mammalian target of rapamycin kinase (mTOR) activity [119]. In renal cystic cells mTOR leads to abnormal cyst formation. Based on this hypothesis, several studies have been conducted to examine the effects of mTOR inhibitors. Rapamycin is an FDAapproved specific inhibitor of mTOR. It has been shown that rapamycin in rodent models reduces cell proliferation, retards cyst expansion and protects renal function [120]. Further experimental and clinical studies (phase 2 clinical trial with sirolimus and everolimus) are in progress [121]. Other experimental drugs being tested on PKD are summarized in Table 3. 


\section{Renal replacement therapy}

ADPKD patients who progress to ESRD require renal replacement therapy with options similar to other ESRD patients, including dialysis or renal transplantation. Peritoneal dialysis is assumed to result in poorer long-term technique survival because of various renal and non-renal aspects ofADPKD, including enlarged kidneys, abdominal wall complications, leaks, and intestinal perforation [122-125]. However a recent retrospective analysis comparing results of 56 consecutive ADPKD patients to 56 non-diabetic patients with bilateral small kidneys treated with peritoneal dialysis and followed up for over 37 months showed no significant differences in terms of mortality, kidney transplantation-censored technique survival, median death-censored technique survival, the number of patients switched permanently to hemodialysis due to technique failure or the rate of peritonitis [126]. Other centers have found that peritoneal dialysis is well tolerated and results in no specific difficulties in patients with ADPKD requiring renal replacement therapy [127]. Although the outcomes are usually good, there are some issues in the renal transplant recipient that are specific for ADPKD, including potential need for nephrectomy and higher rate of complications; namely post-transplant erythrocytosis, symptomatic aneurysms, urinary tract infections, diverticulitis, and gastrointestinal disorders requiring surgery [128-130]. Some patients require unilateral or bilateral nephrectomy in order to better accommodate the allograft, or because of recurrent UTI, chronic pain, or chronic hematuria [131, 132].

\section{Conclusion}

Recent advances in the genetic and molecular basis of ADPKD have yielded exciting approaches towards treatment. In early disease, parameters of renal function remain normal despite progressive and irreversible enlargement of the kidneys with parenchymal distortion. It is therefore prudent, as suggested by the CRISP study [7], that the change in kidney volume, rather than renal function parameters, be used as a marker of response to new therapies. Findings from the ongoing HALT PKD study should settle the role of RAAS blockade in renal and cardiac outcomes for ADPKD. Current clinical trials investigating multiple therapeutic targets bring hope for treatments that may impede the progression of ADPKD.

\section{Acknowledgment}

The authors are supported by a grant from the National Institute of Health/National Institute of Diabetes and Digestive and Kidney Diseases (UO1 DK62402). Elwaleed Elhassan would like to thank the International Society of Nephrology (ISN) for giving him the opportunity to work on ADPKD research in Colorado through the ISN fellowship grant.

\section{References}

1. Ecder T, Fick-Brosnahan G, Schrier RW. Polycystic kidney disease. In: Schrier RW, editor. Diseases of the Kidney and Urinary Tract. 8th ed. Philadelphia (PA): Lippincott Williams \& Wilkins; 2006.

2. Grantham J, Cowley B, Torres VE. Progression of autosomal dominant polycystic kidney disease (ADPKD) to renal failure. In: Seldin D, Giebisch G, editors. The Kidney: Physiology and Pathophysiology. Vol. 2. Philadelphia: Lippincott Williams and Wilkins, 2000. p. 2513-2536.

3. Pei Y. Diagnostic approach in autosomal dominant polycystic kidney disease. Clin J Am Soc Nephrol. 2006;1(5):1108-14.

4. Kimberling WJ, Kumar S, Gabow PA, Kenyon JB, Connolly CJ, Somlo S. Autosomal dominant polycystic kidney disease: Localization of the second gene to chromosome 4q13-q23. Genomics. 1993;18(3):467-72.

5. Igarashi P, Somlo S. Genetics and pathogenesis of polycystic kidney disease. J Am Soc Nephrol. 2002;13(9):2384-98.

6. Persu A, Duyme M, Pirson Y, Lens XM, Messiaen $\mathrm{T}$, Breuning $\mathrm{MH}$, Chauveau D, Levy M, Grünfeld JP, Devuyst O. Comparison between siblings and twins supports a role for modifier genes in ADPKD. Kidney Int. 2004;66(6):2132-6.

7. Grantham JJ, Torres VE, Chapman AB, Guay-Woodford LM, Bae KT, King BF Jr, Wetzel LH, Baumgarten DA, Kenney PJ, Harris PC, Klahr S, Bennett WM, Hirschman GN, Meyers CM, Zhang X, Zhu F, Miller JP; CRISP Investigators. Volume progression in polycystic kidney disease. N Engl J Med. 2006;354(20):2122-30.

8. Hateboer N, v Dijk MA, Bogdanova N, Coto E, SaggarMalik AK, San Millan JL, Torra R, Breuning M, Ravine D. Comparison of phenotypes of polycystic kidney disease types 1 and 2. Lancet. 1999; 353(9147):103-7.

9. Hateboer N. Clinical management of polycystic kidney disease. Clin Med. 2003;3(6):509-12.

10. Chapman AB, Guay-Woodford LM, Grantham JJ, Torres VE, Bae KT, Baumgarten DA, Kenney PJ, King BF Jr, Glockner JF, Wetzel LH, Brummer ME, O'Neill WC, Robbin ML, Bennett WM, Klahr S, Hirschman GH, Kimmel PL, Thompson PA, Miller JP; Consortium for Radiologic Imaging Studies of Polycystic Kidney Disease cohort. Renal structure in early autosomal dominant polycystic kidney disease (ADPKD): the Consortium for 
Radiologic Imaging Studies of Polycystic Kidney Disease (CRISP) cohort. Kidney Int. 2003;64(3):1035-45.

11. Bae KT, Zhu F, Chapman AB, Torres VE, Grantham JJ, Guay-Woodford LM, Baumgarten DA, King BF Jr, Wetzel LH, Kenney PJ, Brummer ME, Bennett WM, Klahr S, Meyers CM, Zhang X, Thompson PA, Miller JP; Consortium for Radiologic Imaging Studies of Polycystic Kidney Disease (CRISP). Magnetic resonance imaging evaluation of hepatic cysts in early autosomal dominant polycystic kidney disease. Clin J Am Soc Nephrol. 2006;1(1):64-9.

12. Torres VE, King BF, Chapman AB, Brummer ME, Bae KT, Glockner JF, Arya K, Risk D, Felmlee JP, Grantham JJ, Guay-Woodford LM, Bennett WM, Klahr S, Meyers CM, Zhang X, Thompson PA, Miller JP; Consortium for Radiologic Imaging Studies of Polycystic Kidney Disease (CRISP). Magnetic resonance measurements of renal blood flow and disease progression in autosomal dominant polycystic kidney disease. Clin J Am Soc Nephrol. 2007;2(1):112-20.

13. King BF, Torres VE, Brummer ME, Chapman AB, Bae KT, Glockner JF, Arya K, Felmlee JP, Grantham JJ, Guay-Woodford LM, Bennett WM, Klahr S, Hirschman GH, Kimmel PL, Thompson PA, Miller JP; Consortium for Radiologic Imaging Studies of Polycystic Kidney Disease (CRISP). Magnetic resonance measurements of renal blood flow as a marker of disease severity in autosomal-dominant polycystic kidney disease. Kidney Int. 2003;64(6):2214-21.

14. O’Neill WC, Robbin ML, Bae KT, Grantham JJ, Chapman AB, Guay-Woodford LM, Torres VE, King BF, Wetzel LH, Thompson PA, Miller JP. Sonographic assessment of the severity and progression of autosomal dominant polycystic kidney disease: The Consortium of Renal Imaging Studies in Polycystic Kidney Disease (CRISP). Am J Kidney Dis. 2005;46(6):1058-64.

15. Rule AD, Torres VE, Chapman AB, Grantham JJ, Guay-Woodford LM, Bae KT, Klahr S, Bennett WM, Meyers CM, Thompson PA, Miller JP; CRISPConsortium. Comparison of methods for determining renal function decline in early autosomal dominant polycystic kidney disease: the consortium for radiologic imaging studies of polycystic kidney disease cohort. J Am Soc Nephrol. 2006;17(3):854-62.

16. Martinez-Maldonado M, Yium JJ, Eknoyan G, Suki WN. Adult polycystic kidney disease: studies of the defect in urine concentration. Kidney Int. 1972;2(2):107-113.

17. Torres VE. Vasopressin antagonists in polycystic kidney disease. Kidney Int. 2005;68(5):2405.
18. Gattone VH 2nd, Wang X, Harris PC, Torres VE. Inhibition of renal cystic disease development and progression by a vasopressin $\mathrm{V} 2$ receptor antagonist. Nat Med. 2003;9(10):1323-6.

19. Torres VE, Keith DS, Offord KP, Kon SP, Wilson DM. Renal ammonia in autosomal dominant polycystic kidney disease. Kidney Int. 1994;45(6):1745-53.

20. Gabow PA. Autosomal dominant polycystic kidney disease. N Engl J Med. 1993;329(5):332-42.

21. Gabow PA, Duley I, Johnson AM. Clinical profiles of gross hematuria in autosomal dominant polycystic kidney disease. Am J Kidney Dis. 1992;20(2):140-3.

22. Torres VE, Wilson DM, Hattery RR, Segura JW. Renal stone disease in autosomal dominant polycystic kidney disease. Am J Kidney Dis. 1993;22(4):513-9.

23. Leoncini G, Sacchi G, Viazzi F, Ravera M, Parodi D, Ratto E, Vettoretti S, Tomolillo C, Deferrari G, Pontremoli R. Microalbuminuria identifies overall cardiovascular risk in essential hypertension: an artificial neural networkbased approach. J Hypertens. 2002;20(7):1315-21.

24. Pontremoli R, Leoncini G, Ravera M, Viazzi F, Vettoretti S, Ratto E, Parodi D, Tomolillo C, Deferrari G. Microalbuminuria, Cardiovascular, and Renal Risk in Primary Hypertension. J Am Soc Nephrol. 2002;13 Suppl 3:S169-S172.

25. Chapman AB, Johnson AM, Gabow PA, Schrier RW. Overt proteinuria and microalbuminuria in autosomal dominant polycystic kidney disease. J Am Soc Nephrol. 1994;5(6):1349-54.

26. Ecder T, Chapman AB, Brosnahan GM, Edelstein CL, Johnson AM, Schrier RW. Effect of antihypertensive therapy on renal function and urinary albumin excretion in hypertensive patients with autosomal dominant polycystic kidney disease. Am J Kidney Dis. 2000;35:427-32.

27. Chapman AB, Schrier RW. Pathogenesis of hypertension in autosomal dominant polycystic kidney disease. Semin Nephrol. 1991;11(6):653-60.

28. Gabow PA, Chapman AB, Johnson AM, Tangel DJ, Duley IT, Kaehny WD, Manco-Johnson M, Schrier RW. Renal structure and hypertension in autosomal dominant polycystic kidney disease. Kidney Int. 1990;38(6):117780 .

29. Kelleher CL, McFann KK, Johnson AM, Schrier RW. Characteristics of hypertension in young adults with autosomal dominant polycystic kidney disease. Am J Hypertens. 2004;17(11 Pt 1):1029-34.

30. Seeman T, Dusek J, Vondrák K, Bláhová K, Simková E, Kreisinger J, Dvorák P, Kyncl M, Hríbal Z, Janda J. 
Renal concentrating capacity is linked to blood pressure in children with autosomal dominant polycystic kidney disease. Physiol Res. 2004;53(6):629-34.

31. Chapman AB, Johnson AM, Rainguet S, Hossack K, Gabow P, Schrier RW. Left ventricular hypertrophy in autosomal dominant polycystic kidney disease. J Am Soc Nephrol. 1997;8(8):1292-7.

32. Sedman A, Bell P, Manco-Johnson M, Schrier R, Warady BA, Heard EO, Butler-Simon N, Gabow P. Autosomal dominant polycystic kidney disease in childhood: a longitudinal study. Kidney Int. 1987;31(4):1000-5.

33. Fick GM, Johnson AM, Hamamond WS, Gabow PA. Causes of death in autosomal dominant polycystic kidney disease. J Am Soc Nephrol. 1995;5(12):2048-56.

34. Ettinger A, Kahn PC, Wise HM Jr. The importance of selective renal angiography in the diagnosis of polycystic disease. J Urol. 1969;102(2):156-61.

35. Jones DB. Arterial and glomerular lesions associated with severe hypertension: light and electron microscopic studies. Lab Invest. 1974;31(4):303-3.

36. Torres VE, Donovan KA, Scicli G, Holley KE, Thibodeau SN, Carretero OA, Inagami T, McAteer JA, Johnson CM. Synthesis of renin by tubulocystic epithelium in autosomal-dominant polycystic kidney disease. Kidney Int. 1992;42(2):364-73.

37. Loghman-Adham M, Soto CE, Inagami T, Cassis L. The intrarenal renin-angiotensin system in autosomal dominant polycystic kidney disease. Am J Physiol Renal Physiol. 2004;287(4):F775-88.

38. Klein IH, Ligtenberg G, Oey PL, Koomans HA, Blankestijn PJ. Sympathetic activity is increased in polycystic kidney disease and is associated with hypertension. J Am Soc Nephrol 2001;12(11):2427-33.

39. Munemura C, Uemasu J, Kawasaki H. Epidermal growth factor and endothelin in cyst fluid from autosomal dominant polycystic kidney disease cases: possible evidence of heterogeneity in cystogenesis. Am J Kidney Dis. 1994;24(4):561-8.

40. Wilson P. Mechanisms of disease: Polycystic kidney disease. N Engl J Med. 2004;350:151-64.

41. Munemura C, Uemasu J, Kawasaki H. Epidermal growth factor and endothelin in cyst fluid from autosomal dominant polycystic kidney disease cases: possible evidence of heterogeneity in cystogenesis. Am J Kidney Dis. 1994; 24(4):561-8.
42. Masoumi A, Reed-Gitomer B, Kelleher C, Schrier RW. Potential Pharmacological Interventions in Polycystic Kidney Disease. Drugs. 2007;67(17):2495-510.

43. Seeman T, Dusek J, Vondrichová H, Kyncl M, John U, Misselwitz J, Janda J. Ambulatory blood pressure correlates with renal volume and number of renal cysts in children with autosomal dominant polycystic kidney disease. Blood Press Monit. 2003;8(3):107-10.

44. Iglesias CG, Torres VE, Offord KP, Holley KE, Beard CM, Kurland LT. Epidemiology of adult polycystic kidney disease, Olmsted County, Minnesota. Am J Kidney Dis. 1983;2(6):630-9.

45. Chapman AB, Johnson AM, Gabow PA. Pregnancy outcome and its relationship to progression of renal failure in autosomal dominant polycystic kidney disease. J Am Soc Nephrol. 1994;5(5):1178-85.

46. Reynolds DM, Falk CT, Li A, King BF, Kamath PS, Huston J 3rd, Shub C, Iglesias DM, Martin RS, Pirson Y, Torres VE, Somlo S. Identification of a locus for autosomal dominant polycystic liver disease, on chromosome 19p13.2-13.1. Am J Hum Genet. 2000;67(6):1598-604.

47. Qian Q, Li A, King BF, Kamath PS, Lager DJ, Huston J 3rd, Shub C, Davila S, Somlo S, Torres VE. Clinical profile of autosomal dominant polycystic liver disease. Hepatology. 2003;37(1):164-171.

48. Gabow PA, Johnson AM, Kaehny WD, MancoJohnson ML, Duley IT, Everson GT. Risk factors for the development of hepatic cysts in autosomal dominant polycystic kidney disease. Hepatology. 1990;11(6):1033-7.

49. Fabris L, Cadamuro M, Fiorotto R, Roskams T, Spirlì C, Melero S, Sonzogni A, Joplin RE, Okolicsanyi L, Strazzabosco M. Effects of angiogenic factor overexpression by human and rodent cholangiocytes in polycystic liver diseases. Hepatology. 2006;43(5):100112.

50. Nichols MT, Gidey E, Matzakos T, Dahl R, Stiegmann G, Shah RJ, Grantham JJ, Fitz JG, Doctor RB. Secretion of cytokines and growth factors into autosomal dominant polycystic kidney disease liver cyst fluid. Hepatology. 2004;40(4):836-46.

51. Everson GT, Scherzinger A, Berger-Leff N, Reichen J, Lezotte D, Manco-Johnson M, Gabow P. Polycystic liver disease: Quantitation of parenchymal and cyst volumes from computed tomography images and clinical correlates of hepatic cysts. Hepatology. 1988;8(6):16273 .

52. Torres VE, Rastogi S, King BF, Stanson AW, Gross JB Jr, Nagorney DM. Hepatic venous outflow obstruction 
in autosomal dominant polycystic kidney disease. J Am Soc Nephrol. 1994;5(5):1186-92.

53. Russell RT, Pinson CW. Surgical management of polycystic liver disease. World J Gastroenterol. 2007;13(38):5052-9.

54. Telenti A, Torres VE, Gross JB Jr, Van Scoy RE, Brown ML, Hattery RR. Hepatic cyst infection in autosomal dominant polycystic kidney disease. Mayo Clin Proc. 1990;65(7):933- 42.

55. Grünfeld JP, Albouze G, Jungers P, Landais P, Dana A, Droz D, Moynot A, Lafforgue B, Boursztyn E, Franco D. Liver changes and complications in adult polycystic kidney disease. Adv Nephrol Necker Hosp. 1985;14:120.

56. Danaci M, Akpolat T, Baştemir M, Sarikaya S, Akan H, Selçuk MB, Cengiz K. The prevalence of seminal vesicle cysts in autosomal dominant polycystic kidney disease. Nephrol Dial Transplant. 1998;13(11):2825-8.

57. Nicolau C, Torra R, Bianchi L, Vilana R, Gilabert R, Darnell A, Brú C. Abdominal sonographic study of autosomal dominant polycystic kidney disease. J Clin Ultrasound. 2000;28(6):277-82.

58. Başar O, Ibiş M, Uçar E, Ertuğrul I, Yolcu OF, Köklü S, Parlak E, Ulker A. Recurrent pancreatitis in a patient with autosomal-dominant polycystic kidney disease. Pancreatology. 2006;6(1-2):160-2.

59. Wijdicks EF, Torres VE, Schievink WI. Chronic subdural hematoma in autosomal dominant polycystic kidney disease. Am J Kidney Dis. 2000;35(1):40-3.

60. Schievink W, Torres VE. Spinal meningeal diverticula in autosomal dominant polycystic kidney disease. Lancet. 1997;349(9060):1223-4.

61. Morris-Stiff G, Coles G, Moore R, Jurewicz A, Lord R. Abdominal wall hernia in autosomal dominant polycystic kidney disease. Br J Surg. 1997;84(5):615-7.

62. Wiebers DO, Whisnant JP, Huston J 3rd, Meissner I, Brown RD Jr, Piepgras DG, Forbes GS, Thielen K, Nichols D, O'Fallon WM, Peacock J, Jaeger L, Kassell NF, Kongable-Beckman GL, Torner JC; International Study of Unruptured Intracranial Aneurysms Investigators. Unruptured intracranial aneurysms: natural history, clinical outcome, and risks of surgical and endovascular treatment. Lancet. 2003;362(9378):103-10.

63. Chapman AB, Rubinstein D, Hughes R, Stears JC, Earnest MP, Johnson AM, Gabow PA, Kaehny WD. Intracranial aneurysms in autosomal dominant polycystic kidney disease. N Engl J Med. 1992; 327(13):916-20.
64. Rinkel GJ, Djibuti M, Algra A, van Gijn J. Prevalence and risk of rupture of intracranial aneurysms: a systemic review. Stroke. 1998;29(1):251-6.

65. Schievink WI, Torres VE, Piepgras DG, Wiebers DO. Saccular intracranial aneurysms in autosomal dominant polycystic kidney disease. J Am Soc Nephrol. 1992;3(1):88-93.

66. Inagawa $T$. Trends in incidence and case fatality rates of aneurismal subarachnoid hemorrhage in Izumo City, Japan, between 1980-1989 and 1990-1998. Stroke. 2001;32(7):1499-507.

67. Belz MM, Hughes RL, Kaehny WD, Johnson AM, Fick-Brosnahan GM, Earnest MP, Gabow PA. Familiar clustering of ruptured intracranial aneurysms in autosomal dominant polycystic kidney disease. Am J Kidney Dis. 2001;38(4):770-6.

68. Belz MM, Fick-Brosnahan GM, Hughes RL, Rubinstein D, Chapman AB, Johnson AM, McFann KK, Kaehny WD, Gabow PA. Recurrence of intracranial aneurysms in autosomal-dominant polycystic kidney disease. Kidney Int. 2003;63(5):1824-30.

69. Chauveau D, Pirson Y, Verellen-Dumoulin C, Macnicol A, Gonzalo A, Grunfeld JP. Intracranial aneurysms in autosomal dominant polycystic kidney disease. Kidney Int. 1994;45(4):1140-6.

70. Rubinstein D, Sandberg EJ, Breeze RE, Sheppard SK, Perkins TG, Cajade-Law AG, Simon JH. T2-weighted three-dimensional turbo spin-echo MR of intracranial aneurysms. AJNR Am J Neuroradiol. 1997;18(10): 1939-43.

71. Torres VE, Harris PC, Pirson Y. Autosomal dominant polycystic kidney disease. Lancet. 2007;369(9569):1287301.

72. Gibbs GF, Huston J 3rd, Qian Q, Kubly V, Harris PC, Brown RD Jr, Torres VE. Follow-up of intracranial aneurysms in autosomal-dominant polycystic kidney disease. Kidney Int. 2004;65(5):1621-27.

73. Huston J 3rd, Torres VE, Wiebers DO, Schievink WI. Follow-up of intracranial aneurysms in autosomal dominant polycystickidney disease by magnetic resonance angiography. J Am Soc Nephrol. 1996;7(10):2135-41.

74. Ivy DD, Shaffer EM, Johnson AM, Kimberling WG, Dobin A, Gabow PA. Cardiovascular abnormalities in children with autosomal dominant polycystic kidney disease. J Am Soc Nephrol. 1995;5(12):2032-6.

75. Cadnapaphornchai MA, McFann K, Strain JD, Masoumi A, Schrier RW. Increased left ventricular mass in children with autosomal dominant polycystic 
kidney disease and borderline hypertension. Kidney Int. 2008;74(9):1192-6.

76. Ecder T, Schrier RW. Hypertension in autosomaldominant polycystic kidney disease: Early occurrence and unique aspects. J Am Soc Nephrol. 2001;12:194200.

77. Hossack KF, Leddy CL, Johnson AM, Schrier RW, Gabow PA. Echocardiographic findings in autosomal dominant polycystic kidney disease. $\mathrm{N}$ Engl J Med. 1988;319(14):907-12.

78. Lumiaho A, Ikäheimo R, Miettinen R, Niemitukia L, LaitinenT, RantalaA,LampainenE,LaaksoM,Hartikainen J. Mitral valve prolapsed and mitral regurgitation are common in patients with polycystic kidney disease type 1. Am J Kidney Dis. 2001;38(6):1208-16.

79. Leier CV, Baker PB, Kilman JW, Wooley CF. Cardiovascular abnormalities associated with adult polycystic kidney disease. Ann Intern Med. 1984;100(5):683-8.

80. Milutinovic J, Fialkow PJ, Agodoa LY, Phillips LA, Rudd TG, Sutherland S. Clinical manifestations of autosomal dominant polycystic kidney disease in patients older than 50 years. Am J Kidney Dis. 1990;15(3):23743.

81. Milutinovic J, Fialkow PJ, Agodoa LY, Phillips LA, Rudd TG, Bryant JI. Autosomal dominant polycystic kidney disease: symptoms and clinical findings. Q J Med. 1984;53(212):511-22.

82. Bajwa ZH, Gupta S, Warfield CA, Steinman TI. Pain management in polycystic kidney disease. Kidney Int. 2001;60(5):1631-44.

83. Sklar AH, Caruana RJ, Lammers JE, Strauser GD. Renal infections in autosomal dominant polycystic kidney disease. Am J Kidney Dis. 1987;10(2):81-8.

84. Bretan PN Jr, Price DC, McClure RD. Localization of abscess in adult polycystic kidney by indium-111 leukocyte scan. 1988;32(2):169-71.

85. Chapman AB, Thickman D, Gabow PA. Percutaneous cyst puncture in the treatment of cyst infection in autosomal dominant polycystic kidney disease. Am J Kidney Dis. 1990;16(3):252-5.

86. Masoumi A, Reed-Gitomer B, Kelleher C, Bekheirnia MR, Schrier RW. Developments in the management of autosomal dominant polycystic kidney disease. Ther Clin Risk Manag. 2008;4(2):393-407.

87. Hetherington JW, Philp MH. Diclofenac sodium versus pethidine in acute renal colic. Br Med J (Clin Res Ed). 1986;292(6515):237-8.
88. Oosterlinck W, Philp NH, Charig C, Gillies G, Hetherington JW, Lloyd J. A double blind single dose comparison of intramuscular ketorolac, tromethamine and pethidine in the treatment of renal colic. J Clin Pharmacol. 1990;30(4):336-41.

89. McIntire SC, Rubenstein RC, Gartner JC Jr, Gilboa N, Ellis D. Acute flank pain and reversible renal dysfunction associated with nonsteroidal antiinflammatory drug use. Pediatrics. 1993;92(3):459-60.

90. Delakas D, Daskalopoulos G, Cranidis A. Extracorporeal shockwave lithotripsy for urinary calculi in autosomal dominant polycystic kidney disease. J Endourol. 1997;11(3):167-70.

91. Torres VE, Wilson DM, Hattery RR, Segura JW. Renal stone disease in autosomal dominant polycystic kidney disease. Am J Kidney Dis. 1993;22(4):513-9.

92. Bajwa ZH, Sial KA, Malik AB, Steinman TI. Pain patterns in patients with polycystic kidney disease. Kidney Int. 2004;66(4):1561-9.

93. Singh I, Mehrotra G. Selective ablation of symptomatic dominant renal cysts using $99 \%$ ethanol in adult polycystic kidney disease. Urology. 2006;68(3):482-7.

94. Casale P, Meyers K, Kaplan B. Follow up for laparoscopic renal denervation and nephropexy for autosomal dominant polycystic kidney disease-related pain in pediatrics. J Endourol. 2008;22(5):991-3.

95. Pretorius DH, Lee ME, Manco-Johnson ML, Weingast GR, Sedman AB, Gabow PA. Diagnosis of autosomal dominant polycystic kidney disease in utero and in the young infant. J Ultrasound Med. 1987;6(5):249-55.

96. Boyer O, Gagnadoux MF, Guest G, Biebuyck N, Charbit M, Salomon R, Niaudet P. Prognosis of autosomal dominant polycystic kidney disease diagnosed in utero or at birth. Pediatr Nephrol. 2007;22(3):380-8.

97. Fick GM, Duley IT, Johnson AM, Strain JD, MancoJohnson ML, Gabow PA. The spectrum of autosomal dominant polycystic kidney disease in children. J Am Soc Nephrol. 1994;4(9):1654-60.

98. Kielstein R, Sass HM. Genetics in kidney disease: how much do we want to know? Am J Kidney Dis. 2002;39(3): 637-52.

99. Pei Y, Obaji J, Dupuis A, Paterson AD, Magistroni R, Dicks E, Parfrey P, Cramer B, Coto E, Torra R, San Millan JL, Gibson R, Breuning M, Peters D, Ravine D. Unified Criteria for Ultrasonographic Diagnosis of ADPKD. J Am Soc Nephrol. 2009;20(1):205-12.

100. Zhao X, Paterson AD, Zahirieh A, He N, Wang $\mathrm{K}$, Pei Y. Molecular diagnostics in autosomal dominant 
polycystic kidney disease: utility and limitations. Clin J Am Soc Nephrol. 2008;3(1):146-52.

101. Ecder T, Schrier RW. Hypertension and left ventricular hypertrophy in autosomal dominant polycystic kidney disease. Expert Rev Cardiovasc Ther. 2004;2(3):369-374.

102. Chapman AB, Johnson AM, Gabow PA, Schrier RW. Overt proteinuria and microalbuminuria in autosomal dominant polycystic kidney disease. J Am Soc Nephrol. 1994;5(6):1349-54.

103. Ecder T, Edelstein CL, Chapman AB, Johnson AM, Tison L, Gill EA, Brosnahan GM, Schrier RW. Reversal of left ventricular hypertrophy with angiotensin converting enzyme inhibition in hypertensive patients with autosomal dominant polycystic kidney disease. Nephrol Dial Transplant. 1999;14(5):1113-6.

104. Ecder T, Edelstein C, Fick-Brosnahan GM, Johnson AM, Chapman AB, Gabow PA, Schrier RW. Diuretics versus angiotensin-converting enzyme inhibitors in autosomal dominant polycystic kidney disease. Am J Nephrol. 2001;21(2):98-103.

105. Klahr S, Breyer JA, Beck GJ, Dennis VW, Hartman JA, Roth D, Steinman TI, Wang SR, Yamamoto ME. Dietary protein restriction, blood pressure control, and the progression of polycystic kidney disease. Modification of Diet in Renal Disease Study Group. J Am Soc Nephrol. 1995;6(4):1318.

106. Maschio G, Alberti D, Janin G, Locatelli F, Mann JF, Motolese M, Ponticelli C, Ritz E, Zucchelli P. Effect of the angiotensin-converting-enzyme inhibitor benazepril on the progression of chronic renal insufficiency: the Angiotensin-Converting-Enzyme Inhibition in Progressive Renal Insufficiency Study Group. N Engl J Med 1996. 334(15):939-45.

107. Schrier R, McFann K, Johnson A, Chapman A, Edelstein C, Brosnahan G, Ecder T, Tison L. Cardiac and renal effects of standard versus rigorous blood pressure control in autosomal dominant polycystic kidney disease: Results of a seven-year prospective randomized study. J Am Soc Nephrol. 2002;13(7):1733-9.

108. Chapman AB. Autosomal Dominant Polycystic Kidney Disease: Time for a Change? J Am Soc Nephrol. 2007;18(5):1399-407.

109. Bomback AS, Klemmer PJ. The incidence and implications of aldosterone breakthrough. Nat Clin Pract Nephrol. 2007;3(9):486-92.

110. Chapman AB. Approaches to testing new treatments in autosomal dominant polycystic kidney disease: insights from the CRISP and HALT-PKD studies. Clin J Am Soc Nephrol. 2008;3(4):1197-204.

111. Devuyst O, Beauwens R. Ion transport and cystogenesis: The paradigm of autosomal dominant polycystic kidney disease. Adv Nephrol. 1998;28:43979.

112. Yamaguchi T, Pelling J, Ramaswamy NT, Eppler JW, Wallace DP, Nagao S, Rome LA, Sullivan LP, Grantham JJ. cAMP stimulates the in vitro proliferation of renal cyst epithelial cells by activating the extracellular signalregulated kinase pathway. Kidney Int. 2000;57(4):1460 71 .

113. Hanaoka K, Guggino WB. cAMP regulates cell proliferation and cyst formation in autosomal polycystic kidney disease cells. J Am Soc Nephrol. 2000;11(7):1179_ 87

114. Torres VE, Wang X, Qian Q, Somlo S, Harris PC, Gattone VH 2nd. Effective treatment of an orthologous model of autosomal dominant polycystic kidney disease. Nat Med. 2004;10(4):363-4.

115. Torres VE, Harris PC, Pirson Y. Autosomal dominant polycystic kidney disease. Lancet. 2007;369(9569):1287301.

116. Nagao S, Nishii K, Katsuyama M, Marunouchi $\mathrm{T}$, Takahashi H, Wallace DP. Increased water intake decreases progression of polycystic kidney disease in the PCK rat. J Am Soc Nephrol. 2006;17(8):2220-7.

117. Torres VE. Water for ADPKD? Probably, yes. J Am Soc Nephrol. 2006;17(8):2089-91.

118. Reichlin S. Somatostatin. N Engl J Med. 1983;309(24):1495-501.

119. Huang S, Houghton PJ. Targeting mTOR signaling for cancer therapy. Curr Opin Pharmacol. 2003;3(4):371-7.

120. Tao Y, Kim J, Schrier RW, Edelstein CL. Rapamycin markedly slows disease progression in a rat model of polycystic kidney disease. J Am Soc Nephrol. 2005;16(1):46-51.

121. Walz G. Therapeutic approaches in autosomal dominant polycystic kidney disease (ADPKD): is there light at the end of the tunnel? Nephrol Dial Transplant. 2006;21(7):1752-7.

122. Del Peso G, Bajo MA, Costero O, Hevia C, Gil F, Díaz C, Aguilera A, Selgas R. Risk factors for abdominal wall complications in peritoneal dialysis patients. Perit Dial Int. 2003;23(3):249-54.

123. De V, Scalamogna A, Scanziani R, Castelnovo C, Dozio B, Rovere G. Polycystic kidney disease and late 
peritoneal leakage in CAPD: are they related? Perit Dial Int. 2002;22(1):82-4.

124. Fletcher S, Turney JH, Brownjohn AM. Increased incidence of hydrothorax complicating peritoneal dialysis in patients with adult polycystic kidney disease. Nephrol Dial Transplant. 1994;9(7):832-3.

125. Graham AN, Neale TJ, Hatfield PJ, Morrison RB, Meech PR, Jacobson A, Faircloth C. End stage renal failure due to polycystic kidney disease managed by continuous ambulatory peritoneal dialysis. N Z Med J. 1986;99(805):491-3.

126. Sanjeev Kuma, Stanley L-S Fan, Martin J Raftery, Magdi M Yaqoob. Long term outcome of patients with autosomal dominant polycystic kidney diseases receiving peritoneal dialysis. Kidney Int. 2008;74(7):946-51.

127. Hadimeri H, Johansson AC, Haraldsson B, Nyberg G. CAPD in patients with autosomal dominant polycystic kidney disease. Perit Dial Int. 1998;18(4):429-32.
128. Hadimeri H, Norden G, Friman S, Nyberg G. Autosomal dominant polycystic kidney disease in a kidney transplant population. Nephrol Dial Transplant. 1997;12(7):1431-6.

129. Andreoni KA, Pelletier RP, Elkhammas EA, Davies EA, Bumgardner GL, Henry ML, Ferguson RM. Increased incidence of gastrointestinal surgical complications in renal transplant recipients with polycystic kidney disease. Transplantation. 1999;67(2):262-6.

130. Stiasny B, Ziebell D, Graf S, Hauser IA, Schulze BD. Clinical aspects of renal transplantation in polycystic kidney disease. Clin Nephrol. 2002;58(1):16-24.

131. Glassman DT, Nipkow L, Bartlett ST, Jacobs SC. Bilateral nephrectomy with concomitant renal graft transplantation for autosomal dominant polycystic kidney disease. J Urol. 2000;164(3 Pt 1):661-4.

132. Fuller TF, Brennan TV, Feng S, Kang SM, Stock PG, Freise CE. End stage polycystic kidney disease: indications and timing of native nephrectomy relative to kidney transplantation. J Urol. 2005;174(6):2284-8. 